\title{
Writing as Possibility: Poetic Practices and Pedagogy
}

\author{
Kelly Young \\ York University
}

Movies....like novels, poems, paintings, they tap realms of imaginative possibility; if they are works of art, they embody their makers' vision of the world. They offer alternative ways of structuring experience, as dreams and other kinds of imaging do.

— Maxine Greene, Teacher as Stranger: Educational Philosophy for the Modern Age.

The longing to produce a double, to express oneself, to pack various lives into this one, to be able to be in several places at once, is, I believe, one of the most powerful and least regarded impulses behind writing. My childhood dreams often had to do with transformations, too.

— Christa Wolf, The Reader and the Writer.

\section{INTERRUPTING THE FAMILIAR: A WORK OF ART}

Art objects interrupt the familiar, notional life or the taken-for-granted meaning of both epistemologies and ontologies by providing an encounter with the other.

Interrupting the familiar through an engagement with a work of art involves an encounter with the other which in turn implies an encounter with the self. What then, is the relationship among works of art, identity and pedagogy? Aesthetic practices involve interpretation and representation while evoking the imagination. Jeanette Winterson (1995) writes:

Art is a way into other realities, other personalities. When I let myself be affected by a book, I let into myself new customs and new desires. The book does not reproduce me, it re-defines me, pushes at my boundaries, shatters the palings that guard my heart Strong texts work along the borders of our minds and alter what already exists. 
For Winterson (1995), text is a narrative that is not limited to notions of a literary text. Rather, paintings, films, and sculptures are all narratives. So what might aesthetic practices, interpretation and representation have to do with pedagogy? Juxtaposing works of art with curriculum and literary theory evokes a transformation through interpretative and representative responses on behalf of the learner. Aesthetic interpretive practices evoke a world of interpretation.

In order to bring forth a world of interpretation, Michèle Barrett (1999) suggests that individuals engage in aesthetic interpretive practices involving fictional, imaginative and aesthetic dimensions of art. Her chapter entitled: "Words and Things," presents a trajectory of "the movement of ideas" through various theories and across disciplines. She writes: "Meaning is constructed through the counterposition of differing elements, whose definition lies precisely in their difference from each other." With an understanding of knowledge as something that is constructed, Barrett inquires into how objects of study, or rather, methods of study, are undertaken with/in disciplines. She writes:

To refer to these differences of method and epistemology is to raise the question of how objects of study are constituted within the various disciplines.... On the contrary, to address the specific 'truths' of the different disciplines is to discover not the controlling modernism of a full integrated general theory of knowledge, but precisely the reverse - an incommensurability of knowledges that provides interesting reflection.

Objects of study in various disciplines require reflection in the same way that interpretive inquiry involves reactionary responses to works of art. What follows is a reflective narrative account of my interpretive journey of learning how to learn to write poetry.

\section{POETRY AS RESEARCH IN TEACHING AND LEARNING}

Reading poetry as an interpretive practice involves a return to memory and history while constructing new meaning. Poetry is a cultural object because it is culturally announced as such. For example, a painting displayed in a gallery is announced as a cultural artifact in the same way that works of fiction and poetry are labeled "fiction" and "poetry" in bookstores and libraries. Individuals engage in new interpretive practices with cultural artifacts such as literary works and paintings. Interpretive practices involve a returning to both personal and collective memory and history while narrating a sense of self. Juxtaposing works of art with theory evokes a transformation through interpretative and representative responses on behalf of the learner through aesthetic interpretive practices opening up what Maxine Greene (1995) refers to as "gaps" that demand identification on behalf of the interpreter. Consequently, interpretation has something to do with human engagements of aesthetic objects and the making of identity. As an educator, I am learning that form has everything to do with the transformation on behalf of the interpreter while reinforcing the need for critical hermeneutic interpretation 
practices to address the notion of human subjectivity in pedagogical settings. My writing of poetry included timed writings and free writing response practices. These practices have helped me interpret my sense of self as educator and poet in relation to the world as I documented a journey of investigating how I learn.

My research has brought forth a world of interpretation as I write about my learning process. I have worked with a research question: "What would happen if I learned to write poetry?" I theorized my learning process and documented my revision process. I consider writing as a place of possibility. My interpretation of readings, conditioned writing practices such as timed writings and my documentation about the ways in which I am learning how to learn, all frame my inquiry and help me to answer my research question. My inquiry began during a graduate independept reading course entitled: Culture, Narrative forms, Memory: An Interpretive Practice. Throughout my research, I examined some of the conceptual issues of interest to educators in the areas of literary interpretive practices, the poetic imagination, the curriculum and the interrelationship among these areas. I engaged in a critical inquiry into writing practices that included written responses to poetry and fiction. My responses were interpreted through a hermeneutic inquiry that involved reading works of poetry and fiction juxtaposed with theoretical texts. My responses were framed by a requirement that past, present and future experiences be interpreted through an act of hermeneutic interpretation as conceptualized by Gadamer (1990). ${ }^{2}$ Writing became a place of possibility for interpretive responses to theory and works of art.

Writing is a practice that develops human cognition and at the same time influences the formation of a human sense of identity. Winterson (1995) understands the complexity of the writing process that involves the imagination, memory, history and highly creative responsive representational forms, as she states:

...when the imaginative capacity is highly developed, it is made up of invention and discernment. Invention is the shaping spirit that re-forms fragments into new wholes, so that even what has been familiar can be seen fresh. Discernment is to know how to test the true and the false and to reveal objects, emotions, ideas in their own coherence. The artist is a translator; one who has learned how to pass into her own language the languages gathered from stones, from birds, from dreams from the body, from the material world, from the invisible world, from sex, from death, from love.

Invention concerns the ambiguousness of creative response, while discernment relates to the quality of the aesthetic form, as interpretive inquiry. The form of my response to readings of poetry and fiction is aesthetic as I invent a discerning response to theory and works of art in poetic form presented throughout this paper. My poem entitled: "Writing Myself into History" (2001) is an exploration of the role of poetry in my life as a poet and curriculum researcher. 
Writing Myself into History

I absorb lessons

from the classroom

move toward

seeing the world anew

inhale each moment

lecture halls

students, texts

rework ruins

of inherited scripts

bear witness

to courage

that flows through

bursts of writing

poetry is a rope that binds us

shared language across tongues

tying knots into ideas

woven through poetic research

the body remembers

aching wrists

musty library stacks

rhythms of key strokes

pulsating on the alphabet

as words colour

the body, mind and soul

the body remembers

breathing

creating worlds made of

fugitive memories, forgotten flesh

and language

as I scribble myself into history

through transformational responses

to traditional ways of

writing in academia.

In my poem "Writing Myself into History" (2001) I trace my "multiple voices" through my imagination, while at the same time, tapping into my courage - to

transform. 10 My experience of writing is explored through writing practices with students in the classroom as well as through my own graduate research. I move from 
what I remember to what the body remembers, outlining my desire to unify body and mind. As both woman and academic, I negotiate the slippery slope of maternal and paternal discourses that liberate and constrict epistemologies and ontologies. I offer my aesthetic transformational poetic response as both a reclaiming of my "selves" and as a documented sketch of my academic journey as a teacher educator.

In both my own graduate independent course and in teacher education classrooms, I use cultural artifacts as a beginning place during writing practices. Together, we interpret and represent our interpretations around familiar and unfamiliar cultural objects through transformational poetic responses. Aesthetic objects used in interpretive writing research practices involve two areas of work. First, responses to works of art are highly creative forms that are juxtaposed and collected for further exploration. Second, building on David Smith's (1991) assertion that hermeneutic inquiry begins with engagement in creative interpretation, the responses that are usually written but not always recorded, are analyzed while attempting to comprehend the relationship between practices of making and using knowledge. 11 Maxine Greene (1995) understands this as she describes a place of interpretation where the imagination lies - as a "gap." Winterson (1995) describes the imagination that lies in the gap. She writes:

Imagination's coin, the infinitely flexible metal of the Muse, metal of the moon, in rounded structure offers new universes, primary worlds, that substantially confront the pretences of notional life. $\stackrel{12}{.}$

The gap that Greene (1995) refers to provides humans with an imaginary space to challenge what Winterson (1995) acknowledges as "notional life." The gap provides interpreters with an opportunity to invent and discern through reactionary interpretive responses to works of art. In other words, as empirical research often uses a cause and effect framework, interpretive inquiry entwines invention and discernment through a highly creative form of aesthetic response to works of art. Elizabeth Vallance (1991) describes aesthetic inquiry as something that is a work of art that is analogous with curriculum. Although aesthetic inquiry takes on various forms such as painting, music, drama and sculpture, among others, and each art form has its own set of references and critics, Vallance (1991) suggests that in pedagogical settings, works of art and curriculum are both artifactual because they are both "constructed" by individuals. Works of art and the curriculum are similar in that they are both forms of communication, both transformational, and both products of a problem-solving process. Curriculum and works of art both invite the audience's and the critic's response and reaction, while providing particular boundaries or frameworks that structure the viewer's perception. ${ }^{13}$ For Vallance (1991), developing aesthetic criticisms of curriculum is difficult work because aesthetic inquiry must convey the salient quality of curriculum using fresh "jargon-free" language that is conveyed through eloquent "good" writing, while revealing a sensitivity to the "telling detail" of the aesthetic response.

Reactions to works of art often involve breaks from the normal ways of seeing the world, as Greene (1973) suggests, aesthetic responses: “...offer alternative ways structuring experience, as dreams and other kinds of imaging do. 15 Similarly, Madeleine Grumet's 
(1988) notion of bodyreading, borrowed from Maurice Merleau-Ponty's (1962) term "body-subject" as human consciousness, moves an understanding of (simplistic) visual interpretation toward an embodied experience, not just the experience of ourselves, but all experience. In her acclaimed article, Bodyreading published in her book Bitter Milk: Women and Teaching (1998), Grumet evokes the image of a cow that ruminates as a reminder that all humans ruminate over works of art providing a bridge between private and public readings, while allowing ourselves to open up and transcend what is hidden in our experience. For Grumet (1988), our experience is then resymbolized in a highly creative form of a work of art.

\section{PEDAGOGICAL POSSIBILITIES OF POETIC RESEARCH}

In order to explore the pedagogical possibilities and implications of interpretive engagements, I have been concerned with what it is like to learn in new ways through an immersion in various aesthetic forms. Tom Barone (1993) suggests that pedagogy involving a student's aesthetic experience has to do with an unfolding of individual storytelling, self-understanding, identification, experience, and imagination, toward a self-transformation along an unfamiliar path. 17 Although in pedagogical settings responses to works of art more often than not relate to literary texts, other works of art such as paintings are objects of study. Pedagogical settings provide locations to examine relationships among cultural aesthetic forms and practices, representational methods and experiences of literary engagement - works of art. Hermeneutic frameworks explore the lived experiences of aesthetic engagement that inform teaching practices and have implications for curriculum theory. ${ }^{18}$ An act of interpretation through an engagement with an aesthetic object can produce interpretive work if particular conditions are set out. For example, while reading Nicole Brossard's (2000) poem entitled: "Portrait," I was reviewing the CBC documentary entitled: "The Other Side of the Picture," directed by Theresa MacInnes, which is an historical overview of women and art in Western society. ${ }^{19}$ Brossard's poem "Portrait" questions the luxury of ambiguity in pedagogy. As I meditated on my interpretation as an interruption of the familiar, I wrote a poetic response. Brossard's poem represents a "gap" whereby I can reflect and see "anew." I spent time juxtaposing her poem in relation to my own identity, my educated imagination, and the $\mathrm{CBC}$ documentary on women and art that depicts museums across North America. My writing practices enabled me to construct and transform my sense of self in relation to theory and works of art. "The Other Side of the Picture" (2001) is my interpretive response to both Brossard's poem (2000) and the CBC documentary.

The Other Side of the Picture

The reality of art is the reality of the imagination. Jeanette Winterson 
The museum is guarded

framed through shades of green

once palettes

part oil, part canvas

priceless - exact

exhibits are

labeled, titled, displayed

found treasures named

form a body narrative

vagrant air chisels my face

throat tightens before

captured savages

depicted in exile

wear blood like threads

subject and object of discipline

private collections

void of fingerprints

identity or dirt

brush strokes

blur hills, pilgrimages

melt tongues stripped of agency

entry rights, desire

where landscapes

resist histories

as yearning foothills

embrace remote mountain culture

on the other side of the picture.

As interpretive practices in educational settings open up what Greene (1995) refers to as "gaps" or "spaces" in order to think about the ways in which identity is relational to others, places, and cultural artifacts - such as a work of art, my reading of Brossard and my interpretation of the CBC's documentary: "The Other Side of the Picture" are complex and interwoven. Similarly, learning to write poetry is research that is transdisciplinary in nature, crossing discourses, among postmodern literary theory, philosophical hermeneutics, aesthetic and curriculum theory, while pushing at the boundaries of academic contexts that traditionally impose rigorous formal rules and structures. Tracing a trajectory of learning to write poetry through intense conditioned interpretive practices that respond to readings of poetry and fiction, encourage me to pay attention to the ways in which form and content are important in the process of writing. My research provided a place to create the necessary conditions to evoke the imagination and to consider the interrelationship between form and content. 
Poetry became a transformational response through poetic form born out of conditions that enabled both an interpretive and representative aesthetic response. Each response evoked the imagination as I was transported back to a journey long forgotten and reinterpreted in light of these texts. Whether responding to visual or textual works of art, what the body remembers and experiences during aesthetic interpretations may not be truly realized, as these experiences are multi-layered and complex. It is by exploring the form and content of works of art toward what Barone (1993) refers to as "a selftransformation along an unfamiliar path" that my aesthetic response emerges. 22 It is through a setting out of particular conditions in pedagogical settings that help individuals evoke the imagination and have reactionary transformational responses to works of art.

The revision process of writing poetry involves an openness and willingness to accept and incorporate feedback into the creative practice. During my writing exercises, I put my poems aside for periods of time and would come back to them again and again. What I have learned through feedback about my poetry whether in my graduate course with Professor Rishma Dunlop or from scholars and writers such as Professor Rebecca Luce-Kapler and Marlene Nourbese Philip and through on-going dialogues with a collective of arts-based researchers entitled the Red Shoes Collective is that I need to rely on images to carry the weight of a poem. A poem is a dream that should not be broken. For a reader, every poem is more than a poem. As I vas revising my poetry, I needed to question every word and develop a strong rhythm. ${ }^{23}$ It became clearer to me that writing is a creative process that emerges through a dialogical practice over a period of time.

My research question: "What would happen if I learned to write poetry?" is complex as it leads to further questions about the ways in which we as learners learn how to learn. Poetry is a method of knowing and is a hermeneutic construction. As I have theorized about what would happen if I learned to write poetry, several areas of interest to curriculum theorists emerged. I learned to write poetry through repetitive writing practices. I began to pay attention to cadence, sound and the form of language in deeper ways than before. I copied out poetry, read it aloud, kept notes on my research journey and documented the etymology of words that informed my writing. In fact, I would say that I became aware of the process and form of writing in ways that I had not understood before. Learning to write poetry has furthered my interest into the ways in which language organizes experience and has influenced my teaching practices. I often spend more time juxtaposing theory and works of art with teacher candidates through conditioned timed writing practices that produce critically interpretive work. Poetry writing involves a creative process that evokes possibilities of exploring relationships among the poetic imagination, curriculum theory and educational practice. 


\section{Notes}

1 Winterson, Jeanette. (1995). Art Objects: Essays on Ecstasy and Effrontery. Toronto: Alfred A. Knopf., 26.

2 Barrett, Michelle. (1999). Imagination in Theory: Culture, Writing, Words, and Things New York: New York University Press., 20.

Ibid., 31-32.

4 Greene, Maxine. (1995). Releasing the Imagination: Essays on Education, the Arts, and Social Change. San Francisco: Jossey Bass Publishers.

5 Ibid.

6 My course was supervised by Professor Rishma Dunlop at York University entitled: Culture, Narrative forms, Memory: An Interpretive Practice, 2001.

7 Gadamer, Hans-Georg. (1990). Truth and Method. ( $2^{\text {nd }}$ Revised edition.) J. Weinsheimer \& D. Marshall Transl.). New York: Crossroad.

8 Winterson, Jeanette. (1995). Art Objects : Essays on Ecstasy and Effrontery. Toronto: Alfred A. Knopf., 146.

9 Young, Kelly. (2001). Writing Myself into History. York University.

10 Greene, Maxine. (1995). Releasing the Imagination: Essays on Education, the Arts, and Social Change. San Francisco: Jossey Bass Publishers, 198.

11 Smith, David. (1991). Hermeneutic Inquiry: The Hermeneutic Imagination and the Pedagogic Text. In Forms of Curriculum Inquiry. Edited by Edmund Short. New York: State University of New York Press.

12 Winterson, Jeanette. (1995). Art Objects : Essays on Ecstasy and Effrontery. Toronto: Alfred A. Knopf.

13 Ibid., 163-4.

14 Ibid., 168-9.

15 Greene, Maxine. (1973). Teacher as Stranger: Educational Philosophy for the Modern Age. California: Wadsworth Publishing., 16.

16 Grumet, Madeleine. (1988). Bodyreading. In Bitter Milk: Women and Teaching. Amherst, MA: University of Massachusetts Press. And Merleau-Ponty, M. (1962). Phenomenology of Perception. London: Routledge \& Kegan Paul.

17 Barone, Tom. (2000). Aesthetics, Politics, and Educational Inquiry: Essays and Examples. New York: Peter Lang.

18 Davis, Brent, Sumara, Dennis J., \& Luce-Kapler, Rebecca. (Eds.) (2000). Engaging Minds: Learning and Teaching in a Complex World. Mahwah, NJ: Lawrence Erlbaum Associates.

19 www.tv.cbc.ca/cbcthursday/PixGyps.html. And Brossard, N. (2000) [1984]. Installations. (Translation by E. Moure and R. Majzels). Original publication 1984, Manitoba: Muses' Co., 35.

20 Winterson, Jeanette. (1995). Art Objects: Essays on Ecstasy and Effrontery. Toronto: Alfred A. Knopf., 40.

21 Young, Kelly. (2001). The Other Side of the Picture. York University.

22 Barone, Tom. (2000). Aesthetics, Politics, and Educational Inquiry: Essays and Examples. New York: Peter Lang.

23 My revision process has been in response to dialogues with Rishm Dunlop in a Graduate Course at York University entitled: Culture, Narrative forms, Memory: An Interpretive Practice, 2001., Rebecca Luce-Kapler an Assistant Professor at Queen's University and Marlene Nourbese Philip as part of the Writer's in Residence Series. (2001). Toronto Women's Bookstore. Toronto, Ontario. In addition, I have on-going dialogues with a collective of arts-based researchers entitled the Red Shoes Collective founded by Rishma Dunlop (2001). 


\section{$\underline{\text { References }}$}

Barone. T. (2000). Aesthetics, Politics, and Educational Inquiry: Essays and Examples. New York: Peter Lang.

Barrett, M. (1999). Imagination in Theory: Culture, Writing, Words, and Things New York: New York University Press.

Brossard, N. (2000). Installations. (Translation by E. Moure and R. Majzels). Original publication 1984, Manitoba: Muses' Co.

Dunlop, R. (2001). Supervisor, Independent Graduate Course entitled: Culture, Narrative forms, Memory: An Interpretive Practice. York Unversity.

Dunlop, R. (2001). Discussion from the Red Shoes Collective. Toronto, Ontario.

Davis, B., Sumara, D., \& Luce-Kapler, R. (Eds.) (2000). Engaging Minds: Learning and Teaching in a Complex World. Mahwah, NJ: Lawrence Erlbaum Associates.

Gadamer, H-G. (1990). Truth and Method. ( $2^{\text {nd }}$. Revised edition.) J. Weinsheimer \& D. Marshall Trans.). New York: Crossroad.

Greene, M. (1995). Releasing the Imagination: Essays on Education, the Arts, and Social Change. San Francisco: Jossey Bass Publishers.

Greene, M. (1973). Teacher as Stranger: Educational Philosophy for the Modern Age. California: Wadsworth Publishing.

Grumet, M. (1988). Bodyreading. In Bitter Milk: Women and Teaching. Amherst, MA: University of Massachusetts Press.

Luce-Kapler, R. (2001). Discussions on Poetry and the Revision Process. Queen's University: Kingston, Ontario

MacInnes, T. The Other Side of the Picture. www.tv.cbc.ca/cbcthursday/PixGyps.html

Merleau-Ponty, M. (1962). Phenomenology of Perception. London: Routledge \& Kegan Paul.

Nourbese Philip, M. (2001). Discussion from the Writer's in Residence Series. Toronto 
Women's Bookstore. Toronto, Ontario.

Smith, D. (1991). Hermeneutic Inquiry: The Hermeneutic Imagination and the Pedagogic Text. In Forms of Curriculum Inquiry. Edited by Edmund Short. New York: State University of New York Press.

Vallance, E. (1991). Aesthetic Inquiry. In Forms of Curriculum Inquiry. Edited by Edmund Short. New York: State University of New York Press.

Winterson, J. (1995). Art Objects: Essays on Ecstasy and Effrontery. Toronto: Alfred A. Knopf.

Wolf, C. (1993). The Reader and the Writer. A. Stephan (Ed.), In The Author's Dimension: Selected Essays. New York: Farrar, Straus. [1965].

Young, K. (2001). Writing Myself into History. And The Other Side of the Picture. York University. 